\title{
Policy Agenda and Legitimation: Referendums on Interethnic Relations in Central and Eastern Europe
}

\author{
SERGIU GHERGHINA \\ University of Glasgow \\ NANULI SILAGADZE \\ Åbo Akademi Finland
}

\begin{abstract}
The increasing use of referendums in contemporary societies raises several questions about their emergence. Among these, it is unclear why controversial and sensitive issues are subjected to popular vote. So far, limited research has investigated why referendums on interethnic relations are initiated. This article seeks to address this gap in the literature and analyzes these reasons by focusing on all five referendums called on interethnic relations in Central and Eastern Europe. These referendums are those organized in Estonia (1992), Latvia (1998 and 2012), Hungary (2004) and Slovenia (2004). The findings of our qualitative analysis reveal that the initiators were driven either by agenda-setting or policy legitimation incentives.
\end{abstract}

This is an Author's Original Manuscript of an article to be published in Nationalism and Ethnic Studies.

\section{INTRODUCTION}

Referendums reflecting on ethnic and political identities are quite popular in Europe. Since 2014, four such votes took place to demand for either independence (Scotland 2014, Catalonia 2017) or change of status (Crimea 2014, Brexit 2017). These examples are only the tip of the iceberg, the continent having a rich tradition of ethno-based referendums in the last three decades. The emergence of countries following the disintegration of former federations, the accession to the European Union of several countries, peace agreements, regional autonomy demands, the settlement of territorial disputes or citizenship laws were the general categories covered by referendums with an ethnic component. When dealing with these categories, earlier studies have focused on the normative debates surrounding them, the importance of context in the decision-making process, the cues provided by the parties involved in

Address correspondence to Sergiu Gherghina, Department of Politics, University of Glasgow, Adam Smith Building, office 1206, G12 8RT, Glasgow, UK. E-mail: Sergiu.Gherghina@ glasgow.ac.uk 
campaigns, the key determinants for why people supported one of the camps, the implications of policy adoption or typologies meant to differentiate between types and explain their occurrence. ${ }^{1}$

In spite of the extensive literature devoted to particular components of ethnonational identities, little attention has been paid to the reasons referendums on ethnic topics are initiated. To address this gap in the literature, our article analyzes the decisions of referendum initiators to make interethnic issues the object of popular votes. The central argument is that this particular type of referendum can be best understood if analyzed through the lens of a typology with two analytical dimensions: approach towards the status quo (maintaining vs. change) and strategic behavior of the initiators (agenda-setting vs. policy legitimation). Our qualitative empirical analysis uses document analysis of secondary data to identify the causes that determined the choice of the initiators in five referendums in Central and Eastern Europe. The region is an appropriate setting to study this type of referendum due to the existence of multiple ethnicities within state borders, with many long-lasting interethnic issues on the political agenda. We closely investigate all five referendums called on interethnic relations, aimed either at difference elimination or difference managing, ${ }^{2}$ which are in chronological order the following: voting rights for non-citizens (Estonia, 1992), naturalization (Latvia, 1998), dual citizenship (Hungary, 2004), restoring basic rights to ethnic minorities who had been erased from the citizen registry (Slovenia 2004) and Russian as a second official language (Latvia, 2012). We excluded all independence referendums and those on border territorial disputes since they refer more to state formation or inter-state relations rather than inter-ethnic relations within a society.

The remainder of this article proceeds as follows. The first section reviews the literature dealing with reasons for which initiators call for a referendum and provides an original typology. Next we provide an overview of the five analyzed referendums, with some useful background details to better understand their topics. The third section includes an empirical analysis and comparatively assesses the similarities and differences between the five referendums. This section also discusses the most important implications of the findings.

\section{THE DRIVERS FOR INTERETHNIC REFERENDUMS}

Referendums involve ordinary citizens in the decision-making process by providing them the opportunity to vote directly on a public issue, a policy or the content of a law without the mediation of 
state institutions. ${ }^{3}$ The choice that citizens have to make is framed in terms of proposals aimed either at maintaining the status quo or pitted against it. The role of referendums in contemporary political systems is subject to extensive debate. One group of scholars explains that giving voice to ordinary citizens on important state matters is problematic due to the public's lack of competence and understanding, which leave room to elite manipulation. In referendums, citizens become vulnerable to politicians and interest groups, but also to populist and radical discourses, mostly due to their lack of information and poor understanding of the policies to be voted upon. ${ }^{4}$ A different strand of literature argues that referendums are a means to bring more legitimacy to the decision-making process, improve the quality of democracy, make changes more rapidly and expand the debate to the entire demos rather than limiting it to the political elites. ${ }^{5}$ This line of enquiry emphasizes the positive impact of referendums on the political system, with key features that could compensate for the failures of representative democracy.

Rich empirical evidence from around the world supports each of these arguments, showing how the use of referendums can vary broadly between being another weapon in the hands of political elites and making the people count in the decision-making process. ${ }^{6}$ Most referendums are positioned between these two extremes, displaying a combination of features that bring them closer to either the manipulation end of the spectrum or to the genuine voice of the public. Earlier research indicated that institutional factors - the timing, design of the referendums or intervention of external actors - can make a difference with respect to the outcome. ${ }^{7}$ In addition to these features, it is essential to know the reasons behind the initiation of referendums to understand why some topics make the object of popular votes. Previous research has indicated that political actors often use referendums to achieve their goals. ${ }^{8}$ The most prominent goals identified in the literature are attempts to solve intra- or interinstitutional disputes, decouple controversial issues from elections for government, advance the legislative agenda, gain legitimacy for fundamental changes or extend public electoral support. ${ }^{9}$

When narrowing down the scope of analysis to interethnic referendums, the institutionally related reasons have limited applicability. There were situations in which popular votes were used to solve internal party disputes or were the ultimate solution to situations in which state institutions collided. ${ }^{10}$ However, most of these referendums had broad and quite technical topics, related to the performance and characteristics of institutions, very far from the specificity of issues of interethnic relations. Such topics were usually highly divisive and mobilizing at the level of the entire society. We argue that the remaining motives can be clustered in two broad categories: approach towards the status $q u o$ and policy-oriented goals, which are briefly articulated in the following two sub-sections. 


\section{Approach Towards the Status Quo}

The first category is straightforward and lies at the core of decisions in referendums. The referendum is a choice between (usually two) policy alternatives, out of which one is (usually) the status quo. The latter is the default solution that provide voters with a point of reference to assess how risky or costly moving away from the status quo is. ${ }^{11}$ Accordingly, the status quo is often at an advantage due to a certain degree of uncertainty involved by the change. It is unclear whether the new alternatives will achieve the promised outcomes or if they might have negative consequences that are not envisaged. ${ }^{12}$ The status quo bias is higher among poorly informed citizens because the status quo will be better known than the new policy. ${ }^{13}$ Their expectations about the new policy are low and they are risk averse.

These propositions suggest that proposals for change face on average considerably more opposition compared to the protection of the status quo. Interethnic relations augment the challenges because they are sensitive issues, with the potential to be highly divisive, and with consequences on multiple layers. As such, the perceived uncertainty of a new policy and fears that things may go in the unwanted direction can be quite high among particular segments in society. Under these circumstances, a safe bet for a referendum initiator is to go for a popular vote in which the status quo is preserved. To stand a good chance when going against the status quo, the initiator has to advertise the changes as bringing a general advantage to society, either in the form of a more progressive / liberal policy or in the form of solving past conflicts.

We propose this analytical dimension for two reasons. First, in addition to its simplicity and general applicability, there is a balance between the possible approaches of the initiators. With referendums on constitutional amendments or powers of state institutions, the theoretical expectation is - and empirical evidence supports it - that most referendums are called to change the status quo. Second, the likelihood of a contagion effect is fairly limited. For referendums on political system, moral values or economic issues, there is a learning process that can be observed longitudinally (if the country has a series of referendums) or cross-nationally, when countries learn from their neighbors. Since interethnic relations are often country specific, the contagion effect is unlikely to occur. It is difficult to predict, based on past experiences of other countries, which way one referendum will be initiated.

\section{The Policy Dimension: Agenda-Setting and Legitimation}


The idea of agenda-setting playing a role in referendums is not new. In their comprehensive review of the literature Simon Hug and George Tsebelis show the importance of agenda-setting for the outcome. The agenda-setter can influence the result by "sequencing appropriately the questions and exploiting the different preferences among the different individual actors." 14 This conclusion is re-enforced by research showing that voting in many referendums involves heuristics from the side of the citizens who expect and follow cues provided by political parties. ${ }^{15}$ In a similar way, agenda-setting is relevant to explaining the decision to initiate the referendum, not only to shape its outcome. Referendums provide political actors the opportunity to advance their own ideas, and promote their political agenda. ${ }^{16}$ This happens in two ways. First, referendums allow parties to take their ideas outside the parliamentary arena, avoiding the political debate that usually surrounds controversial issues, and eventually bypass an adversarial parliamentary majority, that is when supporters of the political idea are in a minority. Political parties use referendums to promote their interests, sometimes with little consultation with the general public or with those directly impacted on by the referendum outcome. A comparative study of Guatemala, Iraq and Cyprus reveals how in these three countries referendums aiming to bring relevant changes to the constitution or to state structures lacked stakeholder consultation. ${ }^{17}$ As such, there are situations in which political parties organize referendums in isolation from the opinions of political opponents and important constituencies, aiming mainly to pursue their own agenda.

Second, a referendum provides a good opportunity for marginal political players to promote their ideas that would otherwise be less prominent in electoral competitions, as in the Italian case. ${ }^{18}$ In some cases, political parties in opposition use referendums to bring back to the political agenda issues that they own but could not achieve while in government. Furthermore, referendums can be used by non-political actors to bring issues to the agenda. ${ }^{19}$ The 2015 referendum in Slovakia banning same-sex marriage was initiated by a conservative church-backed group called Alliance for Family, which gathered the required number of signatures to initiate a popular vote on the issue. ${ }^{20}$

Political elites also use referendums to foster legitimacy in general and the legitimacy of their policies in particular. Legitimacy in general is enhanced by legislative provisions and by use of referendums: earlier studies have shown that when people have a say in the decision-making process through direct democracy, either on paper or in practice, they have a higher level of subjective regime legitimacy, that is accepting and supporting the state authorities. ${ }^{21}$ Research on peace referendums and power-sharing settlements argue that giving people a voice is crucial for the legitimacy of the new institutions especially when facing divisions between groups along ethnonational lines. ${ }^{22}$ The direct involvement of citizens could counter-balance the selfish interests of elites, that is power or rent- 
seeking opportunities, ${ }^{23}$ which may conflict with the general interests of those affected by the institutional change. In the specific case of power-sharing, its approval in a referendum with consent from the main groups in a divided society is equivalent to high legitimacy ${ }^{24}$ that goes beyond elite selfinterests. An illustrative comparison of this mechanism is between the Northern Irish referendum on the Good Friday Agreement and 2004 referendum in Cyprus. In Northern Ireland, the public was involved and informed throughout the process starting with the election of the parties to negotiate the agreement and ending with the voting. ${ }^{25}$ In the unsuccessful Cyprus referendum, the Annan Plan was negotiated secretively between political elites, the public was poorly involved before voting on the outcome and thus did not support the initiative. ${ }^{26}$

The legitimacy of policies in referendums follow the principle according to which the publicly expressed consent of citizens confers legitimacy on an action. Politicians strive to win a policy debate when they believe that the people favor their position. ${ }^{27}$ For example, the 2015 referendum in Greece against accepting the EU and IMF financial bailout was used by the prime minister and governing parties to strengthen their agenda and legitimize their position. ${ }^{28}$ Research shows how the policyoriented approach of the parties towards referendums is not limited to their own interests. In response to the increasingly observed political alienation of citizens, German political parties adopted direct democracy regulations meant to encourage public decision-making and specific types of political activity. ${ }^{29}$ Their goal was to ensure the legitimacy of the system. The pursuit of any of these goals ensures visibility and publicity for the initiator. They are in the spotlight and can capitalize on the image gained during the referendum. The popularity of political actors usually translates into electoral support, which can be either the direct goal of a referendum or a positive externality.

These arguments indicate how referendums can be a function of the approach towards the status quo and attempt to pursue different policy goals. The two are not mutually exclusive and it is quite common for an initiator to seek the achievement of several goals. Figure 1 presents a two-by-two matrix that clusters on two dimensions the reasons for which interethnic referendums may be initiated. The first dimension is the approach towards the status quo and distinguishes between maintaining or altering the existing context, while the second refers to policies and has agenda-setting and policy legitimation as the two main strategies.

\section{Figure 1 about here}


To illustrate the applicability of the typology, this article applies it to five referendums in Central and Eastern Europe on minority rights and citizenship. The following section provides the contextual information for these popular votes and emphasizes the reasons behind the initiators' decision to call them.

\section{FIVE REFERENDUMS ON MINORITY RIGHTS AND CITIZENSHIP}

These referendums were conducted between 1992 and 2012 in Estonia, Hungary, Latvia and Slovenia. In terms of initiator, two of them were top-down, called by the political elites (Estonia, 1992 and Slovenia, 2004), while the remaining three were bottom-up and had as a basis the collection of signatures from ordinary citizens (Hungary, 2004, Slovenia, 2004 and Latvia, 2012). The latter category is a bit more complex since sometimes the signature collection is organized and coordinated by political parties rather than citizens alone (for example Latvia, 2012). Even then, they still fall under the category of bottom-up referendums due to the avenue used to trigger it. With respect to divisions in society, three of the analyzed referendums were quite divisive as illustrated by their tight results. The referendums organized in 1992 in Estonia and in 1998 in Latvia had a narrow majority shifting the balance (53\%), while for the referendum in 2004 in Hungary the distribution of votes was even tighter ( $51 \%$ to $49 \%$ of those who voted); in the latter case turnout was influenced, as we will see below, by a strategic move of the government. In the remaining two referendums the vote either coincided with the ethnic division of the country or it was a sweeping victory by one of the sides. These two instances confirm earlier observations according to which referendums are not very useful when applied to issues running along the major divisions in society. ${ }^{30}$

The following subsections describe in detail the road to each of the referendums, the reasons behind their organization and the key arguments used during the campaign. We present them in near chronological order, the exception to the rule being the 2012 Latvian referendum that is introduced immediately after the 1998 referendum in the same country.

\section{The 1992 Estonian Referendum on Voting Rights for Non-Citizens}

The citizenship debate between liberal and conservative camps emerged in Estonia at the end of the 1980s as the national independence movement gained momentum. The conservatives emphasized the 
drastic changes in the ethnic composition of Estonia's population due to a solid influx of Russianspeaking immigrants during the Soviet regime. In 1949 the share of non-Estonians was around 10\%, in 1989 it had reached an unprecedented level of 38.5\%. In 1992, the conservative camp eventually won the debate on citizenship that resulted in the re-enactment of the Citizenship Act in February 1992 that was based on the principle of the restitution of the pre-1940 citizenship. According to it, only pre-1940 nationals and their descendants, regardless of their ethnic identification, were eligible to obtain Estonian citizenship by simple registration. Those Estonians who had settled in Estonia after 1940, along with their descendants, were required to follow a set naturalization path. ${ }^{31}$ In the spring of 1992 , the main issues of debate in the Estonian parliament were the constitution and citizenship laws. Parliament decided to subject the draft constitution to a referendum as well as the question of whether people who applied for citizenship should be allowed to vote in the following parliamentary elections. ${ }^{32}$

The representatives of the Russian-speaking population perceived the legislation as discriminatory and believed that the conditions for the acquisition of Estonian citizenship would create a segregated society and impose permanent restrictions on the civil rights of nearly $40 \%$ of Estonia's residents. Estonian officials, on the other hand, considered that by international standards, the law included extremely liberal naturalization procedures. ${ }^{33}$ However, the fact that this question was put to a vote raised problems for Estonia on the international arena. The decision was broadly interpreted as discrimination against Russians residing in Estonia and a violation of their human rights. At the time, the number of applicants for citizenship was quite small, only around 5,000 persons. ${ }^{34}$

The political parties with a more nationalist discourse, such as the Estonian National Independence Party, the Conservatives and the Liberals, argued for the re-establishment of the 1938 constitution. The main question of disagreement was the definition of who should have the right to vote. More moderate politicians of the Centre Party and the Estonian Democratic Labor Party took the stance that all residents of Estonia should be included in the referendum vote, whereas the more nationalist-minded blocs wanted only Estonian nationals to participate. "The prevailing viewpoint was that only Estonian citizens should have the right to make decisions concerning the Estonian state. Moreover, the majority of non-citizens had voted against independence in the referendum on independence." 35 In the end, the Russian-speaking population of 500,000 (out of the country's total population of 1.5 million) was not allowed to participate. ${ }^{36}$ The left centrists recommended a "Yes" vote while the right centrists advised the population to vote "No." The question was largely misunderstood by the public who interpreted the vote as whether or not to give non-Estonians citizenship. ${ }^{37}$ The ballot was rejected by about $53 \%$ of the citizens who turned out. 


\section{The 1998 Latvian referendum on citizenship}

Among the countries analyzed in this article, Latvia is the only one which held a referendum on ethnonational issues twice: in 1998 and 2012. Citizenship was granted in accordance with the 1991 Resolution according to which those who were Latvian citizens before 1940 and their descendants had the right to register as citizens. Those who arrived in Latvia during the Soviet period had the option to become naturalized according to the 1994 Citizenship Law. ${ }^{38}$ However, under the Citizenship Law only 6\% applied for citizenship until 1998 due to the "window system," according to which the numbers of those who could apply for citizenship was limited until 2003 on the basis of age criteria, with priority given to younger age groups. ${ }^{39}$

The citizenship status affects various aspects of life: voting, occupation and residence. In Latvia non-citizens are neither allowed to vote in any type of elections nor to establish a political party. Besides this, they have been prohibited from holding state office, serving as judges or barristers, and taking part in diplomatic and consular service. Apart from this, non-citizens have been prohibited from owning land and other natural resources. In addition, they have received fewer privatization vouchers and a smaller pension. This all contributed to their perception as "second class" residents. ${ }^{40}$ The issue of citizenship also played an essential role during the campaign for the 1993 parliamentary election. Proposals from parties ranged from repatriation of all Soviet-era settlers to a zero option. ${ }^{41}$ By December 1997, as Latvia failed to gain entry to the first level of EU accession talks due to the slow progress of naturalization, the country's president became a vocal supporter for liberalization of citizenship laws.

In June 1998, parliament approved the government's proposal to abolish the naturalization windows, grant citizenship at birth to stateless children and simplify the naturalization procedures for persons over 65 years. ${ }^{42}$ The regulations concerning the status of the unemployed were amended to permit job seekers to register with the State Employment Service (SES) and obtain unemployment benefits without proof of knowledge of Latvian. ${ }^{43}$ The nationalist party, For Fatherland and Freedom / Latvian National Independence Party (TB/LNNK), in government at the time, delayed the promulgation of the new June 1998 amendments until it was clear whether or not the public would decide on the amendments through a referendum. The party was successful in collecting signatures from $10 \%$ of the eligible voters for an initiative to support a popular vote. ${ }^{44}$ 
The president campaigned against the TB/LNNK sponsored referendum, arguing that it would both further damage relations with Russia and hinder Latvia's progress towards EU membership. ${ }^{45}$ The TB/LNNK was not united over the issue of the citizenship law. On the one hand, it actively campaigned for signatures to launch a referendum and then subsequently demanded other changes, such as eliminating citizenship for special achievements and reintroducing a quota for naturalization. On the other hand, the prime minister, a representative of the TB/LNNK, declared that easing the citizenship requirements would facilitate EU membership and serve Latvia's strategic interests. The conservative and nationalist People's Party as well as Latvia's Way strongly opposed the referendum, viewing EU accession primarily as a security issue. The union, For Human Rights in a United Latvia, created by the National Harmony Party, the Socialist Party and the Equal Rights Movement in May 1998 also fully supported the facilitated naturalization and all OSCE recommendations. Latvia was subjected to intense pressure from the Russian Federation and the international community to liberalize the country's citizenship law. The referendum on amendments to the citizenship law was held on the same day as the parliamentary election, on 3 October $1998 .{ }^{46}$ Although the referendum campaign contributed to a strengthened feeling of insecurity among minorities, 53\% of citizens voted for the liberalization of naturalization exams, the rights of non-citizens' children to be granted Latvian citizenship and the abolition of age quotas for naturalization. ${ }^{47}$

\section{The 2012 Latvian Constitutional Referendum on Russian as a Second Official Language}

Russian is the native language for more than a quarter of Latvia's two million population, making up the second largest ethnic group in the country. Several laws were passed by parliament to support and strengthen the use of the Latvian language. In general, there are two different discourses of the ethnocultural nation of Latvia: Latvians do not see the Russian-speaking inhabitants as part of the Latvian nation, while the Russian-speaking inhabitants view themselves as loyal and belonging to Latvia. ${ }^{48}$ Tensions escalated after the parliamentary elections in 2011 when a pro-Russia party, Harmony Centre, became the largest force, winning 31 of the total of 100 seats. It was left out of the coalition government formed by three center-right political parties belonging to the majority population. Since this party had always been perceived as Russian and strongly influenced by Moscow, it had never been invited into the government despite its success in parliamentary elections. ${ }^{49}$ Latvian parties consider Harmony Centre as "a Trojan horse for the Kremlin."50 
The referendum itself was a reaction to the attempt of the National Alliance, formed after the merger between All for Latvia! and TB/LNNK, to make Latvian the only language of instruction in public schools. This political party, in opposition at the time, started a petition for a referendum, but failed to collect the required number of signatures. ${ }^{51}$ A counter-initiative to collect signature for a nationwide referendum was initiated by the non-governmental organization, Mother Tongue. The signature-collecting campaign suffered from a lack of progress until Harmony Centre lined up behind it. $^{52}$ This pro-Russian movement managed to collect over 187,000 signatures, that is more than $12 \%$ of voters, to launch a public vote on the matter, thus forcing the Latvian government to organize a nationwide referendum on Russian as the second state language. ${ }^{53}$

Initially distant from the referendum initiatives, political parties later became active supporters of the two camps. For instance, in the beginning the initiative for Russian as the second official state language was supported only by the party, For Human Rights in United Latvia, that had articulated the interests of the Russian-speaking population for many years, but had failed to win any seats in the last parliamentary elections. The situation changed after one of the leaders of Harmony Centre and the incumbent Mayor of Riga, Nils Ushakov, announced that he had signed the petition. Afterwards, other important party members followed Ushakov's example. In the referendum Harmony Centre supported a "Yes" vote, while the President and Prime Minister of Latvia campaigned for a "No" vote. ${ }^{54}$ The country's president first claimed he would not take part in the referendum, then a few weeks before the vote he announced that he would take part in it, but still described the referendum as "absurd," saying that most people are preoccupied by more serious topics - such as recovery from a recession. Besides, he stressed that the government had already been funding language schools for minorities, that is for Russian-speakers. ${ }^{55}$

The referendum campaign was very emotional and polarizing, resulting in the second-highest turnout of voters in a popular vote $(71.12 \%)$. According to the Latvian legislation, in order to make amendments to the Constitution through a referendum an approval quorum of $50 \%$ had to be met. Taking this into consideration, and the proportion of Latvian and Russian speaking voters, there were no rational grounds to expect the referendum to pass. ${ }^{56}$ There was a consensus among the Latvian political elites, religious associations and civil society about this referendum. Their shared position was that the Latvian language was the foundation of national identity, of the state and its sovereignty. ${ }^{57}$ Latvia's top political leaders, the four Latvian parliamentary parties (three in government and one in opposition), non-governmental organizations, intelligentsia associations, the Lutheran and Catholic church hierarchies, the Jewish community and the rabbinical authority urged voters to turn out and vote 
"No." On the oppositional side stood Harmony Centre, the fringe-nationalist National Bolshevik party and the Russian Orthodox Metropolitanate urging Russian voters to support the referendum. ${ }^{58}$ The outcome of the referendum was "arithmetically predetermined." 59 The vote clearly mirrored the linguistic and ethnic lines in Latvian society: around $75 \%$ voted against and $25 \%$ in favor, corresponding with the proportion of Latvians and Russians / Russophones among Latvia's citizens. ${ }^{60}$ According to the Office of Citizenship and Migration Affairs, there are about $72 \%$ ethnic Latvians, $20 \%$ ethnic Russians and $9 \%$ other ethnicities in Latvia. ${ }^{61}$

\section{The 2004 Hungarian Referendum on Dual Citizenship}

On 5 December 2004, less than half a year after its accession to the EU, Hungary held a referendum to grant dual citizenship to ethnic Hungarians living outside their homeland. The novelty of this proposal was not the dual citizenship itself since it had long been available for permanent residents within the country, but rather removing residency requirements as a pre-condition for obtaining Hungarian second citizenship. Ethnic Hungarians abroad were to be granted Hungarian citizenship merely by declaring themselves as being of Hungarian linguistic affiliation or by confirming their Hungarian ethnicity. The proposal was directed at external minorities - Hungarian diaspora elsewhere in the world. Taking into consideration that the number of ethnic Hungarians in the neighboring states was estimated at around three million and the population of Hungary at that time was about 10 million, and assuming that the majority of those would actually claim citizenship, "the proportions of the resulting change would exceed the growth of Germany's citizenry after unification, but of course, without the corresponding territorial enlargement." 62 The logic of the Hungarian trans-border dual citizenship initiative was fundamentally different from that applied in Western Europe. In the latter, dual citizenship is used to integrate labor migrants into their country of immigration, thus decoupling citizenship from ethnicity. The Hungarian case, in contrast, represents a counter-trend of re-linking citizenship with ethnicity. ${ }^{63}$

The initiative to call for a referendum came from outside the Hungarian political establishment. A radical and rather marginal NGO dedicated to the protection of the Hungarian diaspora, the World Federation of Hungarians, came up with the idea. No political actor would take the risk of launching an initiative that had very limited support within Hungary itself. The NGO succeeded in obtaining the 200,000 signatures necessary for putting its proposal to the ballot. ${ }^{64}$ Initially, the Hungarian political parties reacted very cautiously to the initiative. After several months the mainstream rightwing parties (FIDESZ and MDF) along with the President of the Republic declared their support for the referendum, 
while the socialists and liberals took the opposite position. ${ }^{65}$ The ruling Socialists (MSZP) and their junior coalition partners, the liberal Free Democrats (SZDSZ), were against the proposal, while the opposition parties Young Democrats-Civic Party (FIDESZ-MPP) and Democratic Forum (MDF) campaigned for a "Yes" vote. ${ }^{66}$

The debate was dominated by two great discourses: the "Yes" camp with emphasis on moralism, historicism and emotional exaltation and the "No" camp with a universalist discourse. ${ }^{67}$ The political debates on the referendum within Hungary were highly polarized between the nationalist right as supporters and the Europe-oriented opponents. ${ }^{68}$ The advocates of the referendum argued that their view was based on concepts of an integrated Europe of the future, a de-territorialized world. They emphasized that European states accept ethnicity as part of the basis of citizenship, applying a particularly relevant example of Silesian Germans who, from the early 1990s, were able to obtain German passports in addition to their Polish ones without having residence in Germany. The two mainstream rightwing parties underlined the need to recreate a "unitary Hungarian nation" over and above existing state borders. ${ }^{69}$ The possible dual citizenship for ethnic Hungarians, especially when Viktor Orban linked the issue to greater autonomy for them in neighboring states, met with great disapproval from the states concerned as a threat to their sovereignty. ${ }^{70}$

The "No" camp used welfare protectionism as argument since, apart from Slovakia, the living standards of trans-border Hungarians were way below those in Hungary. The Socialist Party emphasized primarily the costs of the reform. They estimated that 800,000 ethnic Hungarians might migrate to Hungary in the case of a successful referendum, leading to an additional 2.9 billion dollars in welfare expenditures each year. ${ }^{71}$ Another important motive for a "No" vote could have been the fear of instability at the borders due to potential conflicts with Hungary's neighbors. In addition, voters might have been influenced by the perception that dual citizenship would eventually lead to voting rights, thus, allowing those who do not live in the country influence over its politics. Mass enfranchisement of a new electorate could introduce new uncertainties into the system and lead to an internal destabilization of Hungary's relatively young transitional democracy. ${ }^{72}$ The result was invalid since only about $37 \%$ of the eligible voters participated in the referendum. Among these, the $51 \%$ in favor were not sufficient to meet the approval quorum of $25 \%$ of registered voters. ${ }^{73}$ This result was mainly due to the strategic behavior of the "No" camp, which urged people to stay at home since the referendum required an approval quorum. 


\section{The 2004 Slovenian Referendum on Restoring Basic Rights to Ethnic Minorities}

After a one-week conflict with the federal army, Slovenia rapidly distanced itself from the crisis in the former Yugoslavia and unilaterally declared its independence on 25 June $1991 .^{74}$ Though Slovenia had no historical heritage of independent statehood, ${ }^{75}$ it succeeded in establishing itself as a promising candidate for EU accession, being often characterized as an example of human rights protection and respect for the rule of law with its functioning state apparatus. The only spot on this idyllic picture was the case of the so-called erased people (mostly Croats, Bosnians and Serbs). The Slovenian law on Citizenship from June 1991 stated that individuals from other republics who had lawful residence in Slovenia on the day of the independence referendum could become Slovenian citizens upon request within six months. ${ }^{76}$ As a result of this brief window of opportunity that was allowed in 1992, around 18,000 non-Slovene citizens of the former Yugoslavia who remained in Slovenia after independence were administratively removed from the official records after they failed to apply for citizenship or permanent resident status. As a consequence, they were systematically denied driver's licenses, access to state health care and pensions. ${ }^{77}$

In March 2003, the Constitutional Court found this regulation unconstitutional and decided that those who had had their permanent residence approved in the meantime (from 1992 to 2003) should also obtain this status retroactively for the period from 1992 onwards. The restoration of basic rights to ethnic minorities was in line with the EU requirements and recommendations, and was quite a salient issue at the time since the accession was planned the following year. The Ministry of Interior was assigned the task of preparing a law to implement the decision of the Constitutional Court. On this basis, two opposing political camps emerged: the governing Liberal Democracy of Slovenia and the United List of Social Democrats favored the proposal, while the Slovenian Democratic Party (SDS), New Slovenia, Slovenian National Party together with the Slovene People's Party (member of the governing coalition) opposed it. ${ }^{78}$ The polarization of the political scene and public opinion over the topic led to various interpretations of the Constitutional Court decision. ${ }^{79}$ In protest at the government's attempts to regulate the issue of the erased, the main opposition party (SDS) initiated a campaign to collect signatures from the Members of Parliament and succeeded in calling a referendum on 4 April 2004. ${ }^{80}$ According to Article 168 of the Slovenian Constitution, "a proposal to initiate the procedure for amending the Constitution may be made by twenty deputies of the National Assembly, the Government or at least thirty thousand voters." 81 
The parliamentary debates over these bills raised concerns about the stability of the Centre Left government since the coalition and opposition were divided over the issue of restoring the status of the erased. As the crisis heated up the Slovenian President, Janez Drnovšek, interfered and urged all parties to abandon the idea of holding a referendum since, "although it could not overturn a Constitutional Court decision, would nonetheless create further division and encourage nationalist passions." $\$ 2$ Nevertheless, campaigners, led by some members of the opposition, openly articulated that the decision of the Constitutional Court should not be respected. Furthermore, "they spread ethnic hatred and mistrust by claiming that the Erased were non-Slovenes who did not want Slovene citizenship." 83 Slovenia's nationalists argued that after restoring rights to the erased the country would be forced to pay enormous sums for compensation claims. ${ }^{84}$ The paradox of this referendum was reflected in the fact that "a majority voted on an issue concerning a minority which was ineligible to vote." 85 This vote was accompanied by public protests and calls for a boycott, which was supported by the government. In the end, the voter turnout was lower than one third and the proposal to restore basic rights was rejected by almost $95 \%$ of those who voted. ${ }^{86}$

\section{DISCUSSION AND CONCLUSION}

These descriptions of the five referendums indicate the existence of one major reason behind every referendum. They populate three out of the four cells of the matrix and provide room for fruitful comparisons. The two referendums on agenda-setting were the ones in Hungary (2004) and Latvia (2012). They both tried to change the status quo with the help of issues that were not originally on the agenda. The Hungarian referendum was triggered by an idea that was nearly incomprehensible in the broader context of the EU. The expansion of Hungarian citizenship went against that of a Union without borders in which citizenship is meant to be transnational (that is European and less nationalbased). Hungary had become an EU member state in the year of the referendum, while the neighboring countries with important Hungarian diasporas were either members (Slovakia) or set on the path for accession (Romania, 2007 and Croatia, 2013). These are the circumstances that explain the absence of the topic of Hungarian citizenship from the political agenda before being pushed by an NGO.

\section{Figure 2 about here}


The Latvian referendum (2012) was also intended to bring about a change with an issue on which the initiators could not claim ownership. As described, it was a reaction to the initiative of the National Alliance to remove Russian as a language of instruction from public schools. The pro-Russian movement initiating the referendum came with a counter-proposal in which Russian was supposed to become a second state language. Such an issue was not in the spotlight until then, although the 1998 referendum was positive for ethnic minorities. When putting this issue on the agenda, the supporters of the referendum considered it as "an outgrowth of longstanding divisions and historically unequal treatment for the country's large minority of native Russian speakers." 87 For ethnic Latvians the proposal was, in contrast, "an attempt to encroach on Latvia's independence, which was restored two decades ago after half a century of occupation by the Soviet Union." 88 Furthermore, the "No" camp used the slogan "Latvia is for Latvians," arguing that "Russians have Russia, Latvians-Latvia, SwedesSweden etc.." Russians in Latvia were discursively framed as occupants, using the expression that their "grandfathers and grandmothers came here with tanks." 89 Moreover, the question arose: "if Latvians had to know Russian during the Soviet era, why don't Russians now know Latvian after 20 years of an independent Latvia?"90

The referendums in Latvia (1998) and Slovenia (2004) were aimed at maintaining the status quo. In Latvia, the opposition, animated by nationalist discourse, tried to block these aims with the help of the government-initiated referendum to alter the status of non-Latvian citizens. The executive planned to liberalize the naturalization exams, provide non-citizens' children the right to be granted Latvian citizenship and abolish age quotas for naturalization. The policy legitimization attempt of the opposition signaled that the status quo was preferred; the government took some steps in that direction and used a popular vote to ensure the status quo maintenance. In Slovenia, the reform initiated by the Ministry of Interior, following the verdict that a provision in the existing law was unconstitutional, was blocked by the main opposition party SDS. To legitimize its position on the issue of basic rights for ethnic minorities, the SDS initiated a referendum through the required number of signatures from parliamentarians. The result of the referendum was favorable to the SDS. An indication of its legitimizing of the party's policy position was major electoral success for the SDS in the parliamentary elections organized in the same year.

Estonia and Latvia are the only two former Soviet republics that did not introduce the zero option of citizenship after independence. According to the zero option principle all current residents of the state's territory are granted citizenship without the need to go through a process of naturalization. ${ }^{91}$ Their presence in different cells of Figure 1 with the referendums organized on citizenship topics is not 
surprising if we consider that the Estonian referendum was the one initiated by the government to bring reforms, while in Latvia it was a referendum opposing similar government reforms. The 1992 referendum in Estonia was meant to legitimize the new state policy on citizenship after the country gained its independence.

This article aimed to identify the reasons behind the initiation of referendums on ethno-national issues in Central and Eastern Europe. The analysis of all five referendums conducted between 1992 and 2012 indicates that the initiators, either coming from the political elites or from outside the establishment, had two main goals: setting the political agenda and providing legitimacy for their own policies. Equally important, there is a balance between referendums called for the preservation of the status quo and those for its change. This is in line with the theoretical discussion preceding the presentation of the case studies, according to which a balanced approach towards the status quo is expected in these cases.

One major theoretical implication of these findings is that the call for ethno-national referendums can be understood if looking at their approach towards the status quo and policy related goals. Although tested for five referendums, the typology proposed in this article is not geographically and politically confined to the Central and East European space. Its theoretical origins are general and broadly applicable and the limited empirical evidence from this study is mainly due to space constraints. We believe that this typology can be a useful starting point for a systematic analysis of reasons to initiate referendums with an ethnic dimension. This parsimonious categorization paves the way for a better understanding of the logic of this type of popular vote by in-depth scrutiny of contextual factors, allowing at the same time for cross-country and longitudinal comparisons. The empirical implication of this article is the observation that highly divisive issues do not appear to make a difference in terms of initiation. Although there were theoretical reasons to expect that controversial issues and general consensus issues are approached differently by initiators, the empirical evidence reveals the contrary. The summary in Figure 2 includes in the same cell a controversial issue (Latvia, 1998) and one with general consensus (Slovenia, 2004).

Further research can expand the scope of the analysis and include cases from Western Europe to see whether the results are robust in a broader comparison. This would contribute to the empirical merit of the study by providing a guide map for policy-makers about the experiences of this particular type of popular vote. At the same time, qualitative data in the form of interviews with decision-makers could nuance the general observations made here. This new type of information could explain in detail if and 
how the context played a crucial role in deciding in favor of a popular vote to solve interethnic relations, which cannot be captured by the type of analysis conducted in this article.

\section{ACKNOWLEDGMENTS}

The authors are grateful for the constructive comments and useful suggestions provided by the participants at the UPTAKE workshop "Ethnopolitics in Central and Eastern Europe in a State of Flux" (9-10 February 2018, University of Tartu) and to the three anonymous reviewers of this journal.

\section{NOTES}

${ }^{1}$ Roger Mac Ginty, "Constitutional Referendums and Ethnonational Conflict: The Case of Northern Ireland," Nationalism and Ethnic Politics 9, no. 2 (2003): 1-22; Sung Yong Lee and Roger Mac Ginty, "Context and Postconflict Referendums," Nationalism and Ethnic Politics 18, no. 1 (2012): 43-64; Y.V. Tverdova and C.J. Anderson, "Choosing the West? Referendum Choices on EU Membership in East-Central Europe," Electoral Studies 23, no. 2 (2004): 185-208; Sean Hanley, "A Nation of Sceptics? The Czech EU Accession Referendum of 13-14 June 2003," West European Politics 27, no. 4 (2004): 691-715; Nanuli Silagadze and Sergiu Gherghina, "When Who and How Matter: Explaining the Success of Referendums in Europe," Comparative European Politics, no. online first (2017): 1-18; Joanne McEvoy, "Letting 'the People(s)' Decide: Peace Referendums and Power-Sharing Settlements," Democratization 25, no. 5 (2018): 864-81; Neophytos Loizides, "Negotiated Settlements and Peace Referendums," European Journal of Political Research 53, no. 2 (2014): 234-49.; J. M. Mancini and Graham Finlay, "Citizenship Matters': Lessons from the Irish Citizenship Referendum," American Quarterly 60, no. 3 (2008): 575-99; Gabrielle Lynch, "The Fruits of Perception: 'Ethnic Politics' and the Case of Kenya's Constitutional Referendum," African Studies 65, no. 2 (2006): 233-70; David Carey Jr., "Maya Perspectives on the 1999 Referendum in Guatemala," Latin American Perspectives 31, no. 6 (2004): 69-95; Jean-François Mayer, "A Country without Minarets: Analysis of the Background and Meaning of the Swiss Vote of 29 November 2009," Religion 41, no. 1 (2011): 11-28; Erol Kaymak, "If At First You Don’t Succeed, Try, Try Again: (Re)Designing Referenda to Ratify a Peace Treaty in Cyprus," Nationalism and Ethnic Politics 18, no. 1 (2012): 88-112; Zoran Oklopcic, "Independence Referendums and Democratic Theory in Quebec and Montenegro," Nationalism and Ethnic Politics 18, no. 1 (2012): 22-42; Matt Qvortrup, Referendums and Ethnic Conflict (Philadelphia: University of Pennsylvania Press, 2014).

${ }^{2}$ Matt Qvortrup, Referendums and Ethnic Conflict (Philadelphia: University of Pennsylvania Press, 2014).

${ }^{3}$ David Butler and Austin Ranney, eds. Referendums around the World: The Growing Use of Direct Democracy (Basingstoke: Macmillan, 1994); George Williams and David Hume, People Power: The History and Future of the Referendum in Australia (Sydney: University of New South Wales Press Ltd., 2010); David Altman, Direct Democracy Worldwide (Cambridge: Cambridge University Press, 2011).

${ }^{4}$ Gerald Schneider and Patricia A. Weitsman, "The Punishment Trap. Integration Referendums as Popularity Contests," Comparative Political Studies 28, no. 4 (1996): 582-607; Arthur Lupia and Richard Johnston, "Are Voters to Blame? Voter Competence and Elite Maneuvers in Referendums," in Referendum Democracy: Citizens, Elites and Deliberation in Referendum Campaigns, edited by Matthew Mendelsohn and Andrew Parkin (Basingstoke: Palgrave Macmillan, 2001), 191-210; John Highley and Ian McAllister, "Elite Division and Voter Confusion: Australia's Republic Referendum in 1999," European Journal of Political Research 41, no. 4 (2002): 845-61; Ian Budge, "Implementing Popular Preferences: Is Direct Democracy the Answer?," in Evaluating Democratic Innovations. Curing the Democratic Malaise?, edited by Brigitte Geissel and Kenneth Newton (London: Routledge, 2012), 23-38; Matt Qvortrup, "The Rise of Referendums: Demystifying Direct Democracy,” Journal of Democracy 28, no. 3 (2017): 141-52. 
${ }^{5}$ Maija Setala, "On the Problems of Responsibility and Accountability in Referendums," European Journal of Political Research 45, no. 4 (June 2006): 699-721; Altman, Direct Democracy Worldwide; Evaluating Democratic Innovations: Curing the Democratic Malaise?, edited by Brigitte Geissel and Kenneth Newton (London: Routledge, 2012); Sergiu Gherghina, "Direct Democracy and Subjective Regime Legitimacy in Europe," Democratization 24, no. 4 (2017): 613-31; Mark N. Franklin, Cees van der Eijk, and Michael Marsh, "Referendum Outcomes and Trust in Government: Public Support for Europe in the Wake of Maastricht," West European Politics 18, no. 3 (1995): 101-17; Qvortrup, Referendums Around the World. The Continued Growth of Direct Democracy.

${ }^{6}$ Referendums around the World: The Growing Use of Direct Democracy, edited by David Butler and Austin Ranney (Basingstoke: Macmillan, 1994); Matthew Mendelsohn and Andrew Parkin, Referendum Democracy Citizens, Elites and Deliberation in Referendum Campaigns (Basingstoke: Palgrave Macmillan, 2001); Mark Clarence Walker, The Strategic Use of Referendums: Power, Legitimacy, and Democracy (New York: Palgrave Macmillan, 2003); Matt Qvortrup, A Comparative Study of Referendums: Government by the People (Manchester: Manchester University Press, 2005); Matt Qvortrup, Referendums Around the World. The Continued Growth of Direct Democracy (Basingstoke: Palgrave Macmillan, 2014).

${ }^{7}$ Loizides, "Negotiated Settlements and Peace Referendums."

${ }^{8}$ Walker, The Strategic Use of Referendums: Power, Legitimacy, and Democracy.

${ }^{9}$ Ian Budge, "Political Parties in Direct Democracy," in Referendum Democracy: Citizens, Elites and Deliberation in Referendum Campaigns, edited by Matthew Mendelsohn and Andrew Parkin (Basingstoke: Palgrave Macmillan UK, 2001), 67-87; Claes H. de Vreese and Holli A. Semetko, Political Campaigning in Referendums. Framing the Referendum Issue (London: Routledge, 2004); Gideon Rahat, "Elite Motives for Initiating Referendums: Avoidance, Addition and Contradiction," in Referendums and Representative

Democracy Responsiveness, Accountability and Deliberation, edited by Maija Setälä and Theo Schiller (London: Routledge, 2009), 98-116; Mendelsohn and Parkin, Referendum Democracy Citizens, Elites and Deliberation in Referendum Campaigns.

${ }^{10}$ Sergiu Gherghina and Sergiu Miscoiu, "The Failure of Cohabitation: Explaining the 2007 and 2012 Institutional Crises in Romania," East European Politics \& Societies 27, no. 4 (2013): 668-84.

${ }^{11}$ Shaun Bowler and Todd Donovan, Demanding Choices. Opinion, Voting, and Direct Democracy (Ann Arbor: University of Michigan Press, 1999).

${ }^{12}$ Daniel E. Ingberman, "Running Against the Status Quo: Institutions for Direct Democracy Referenda and Allocations over Time," Public Choice 46, no. 1 (1985): 19-43; Thomas Christin, Simon Hug, and Pascal Sciarini, "Interests and Information in Referendum Voting: An Analysis of Swiss Voters," European Journal of Political Research 41, no. 6 (2002): 759-76.

${ }^{13}$ Ibid.

${ }^{14}$ Simon Hug and George Tsebelis, "Veto Players and Referendums Around the World," Journal of Theoretical Politics 14, no. 4 (October 2002): 370.

${ }^{15}$ Susan E. Scarrow, "Parties and the Expansion of Direct Democracy: Who Benefits?," Party Politics 5, no. 3 (1999): 341-62; Christin, Hug, and Sciarini, "Interests and Information in Referendum Voting: An Analysis of Swiss Voters"; Sara Binzer Hobolt, "Taking Cues on Europe? Voter Competence and Party Endorsements in Referendums on European Integration," European Journal of Political Research 46, no. 2 (2007): 151-82. ${ }^{16}$ Andreas Ladner and Michael Brändle, "Does Direct Democracy Matter for Political Parties? An Empirical Test in the Swiss Cantons," Party Politics 5, no. 3 (1999): 283-302.

${ }^{17}$ Kaymak, "If At First You Don't Succeed, Try, Try Again: (Re)Designing Referenda to Ratify a Peace Treaty in Cyprus"; Lee and Mac Ginty, "Context and Postconflict Referendums."

${ }_{18}$ Pier Vincenzo Uleri, "On Referendum Voting in Italy: YES, NO or Non-Vote? How Italian Parties Learned to Control Referendums," European Journal of Political Research 41, no. 6 (2002): 863-83.

${ }^{19}$ Stoycho P. Stoychev and Gergana Tomova, "Campaigning Outside the Campaign: Political Parties and Referendums in Bulgaria," East European Politics \& Societies and Cultures, no. forthcoming (2018).

${ }^{20}$ Marek Rybář and Anna Šovčíková, “The 2015 Referendum in Slovakia," East European Quarterly 44, no. 1-2 (2016): 79-88. 
${ }^{21}$ Sergiu Gherghina, "Direct Democracy and Subjective Regime Legitimacy in Europe," Democratization 24, no. 4 (2017): 613-31.

22 John McGarry, "Conclusion: What Explains the Performance of Power-Sharing Settlements?," in Power-

Sharing: Empirical and Normative Challenges, edited by Allison McCulloch and John McGarry (London:

Routledge, 2017), 268-292; McEvoy, 'Letting 'the People(s)' Decide: Peace Referendums and Power-Sharing Settlements."

${ }^{23}$ Alyssa K. Prorok, "Leader Incentives and Civil War Outcomes," American Journal of Political Science 60, no. 1 (2016): 70-84.

${ }^{24}$ Christopher McCrudden and Brendan O’Leary, Courts and Consociations: Human Rights Versus PowerSharing (Oxford: Oxford University Press, 2013).

${ }^{25}$ Joana Amaral, "Do Peace Negotiations Shape Settlement Referendums? The Annan Plan and Good Friday Agreement Experiences Compared," Cooperation and Conflict, no. online first (2018).

${ }^{26}$ Viola Drath, "The Cyprus Referendum: An Island Divided by Mutual Distrust," American Foreign Policy Interests 26, no. 4 (2004): 341-52; Michális S. Michael, "The Cyprus Peace Talks: A Critical Appraisal," Journal of Peace Research 44, no. 5 (2007): 587-604.

${ }^{27}$ Mark Clarence Walker, The Strategic Use of Referendums: Power, Legitimacy, and Democracy (New York: Palgrave Macmillan, 2003).

${ }^{28}$ Liubomir Topaloff, “Elite Strategy or Populist Weapon?,” Journal of Democracy 28, no. 3 (2017): 127-40.

${ }^{29}$ Scarrow, "Parties and the Expansion of Direct Democracy: Who Benefits?."

${ }^{30}$ Michael Gallagher, "Conclusion," in The Referendum Experience in Europe, edited by Michael Gallagher and Pier Vincenzo Uleri (Houndmills: MacMillan Press, 1996).

${ }^{31}$ Priit Järve, "Estonian Citizenship: Between Ethnic Preferences and Democratic Obligations," in Citizenship Policies in the New Europe, edited by Rainer Bauböck, Bernhard Perchinig, and Wiebke Sievers (Amsterdam: Amsterdam University Press, 2009), 45-66.

32 Jüri Ruus, "Estonia," in Direct Democracy: The Eastern and Central European Experience, edited by Andreas Auer and Michael Butzer (Aldershot: Ashgate Publishing, 2001), 47-62.

${ }^{33}$ Andras Fehervary, "Citizenship, Statelessness and Human Rights: Recent Developments in the Baltic States," International Journal of Refugee Law 5, no. 3 (1993): 392-423.

${ }^{34}$ Ruus, "Estonia."

anonin Financing Referendum Campaigns, edited by Karin Gilland Lutz and Simon Hug (London: Palgrave Macmillan UK, 2010), 81-106.

${ }^{36}$ Stephen Tierney, Constitutional Referendums: The Theory and Practice of Republican Deliberation (Oxford: Oxford University Press, 2012).

${ }^{37}$ Ruus, "Estonia."

${ }^{38}$ Brigita Zepa, "Citizenship, Official Language, Bilingual Education in Latvia: Public Policy in the Last 10 Years," in Baltic States: Looking at Small Societies on Europe's Margin, edited by Christian Giordano, Alina Žvinklienė and Daniel Henseler (Fribourg: University Press, 2003), 86-87.

${ }^{39}$ Anon, "Regular Report from The Commission on Latvia's Progress towards Accession," 1998, 11.

${ }^{40}$ Lowell W. Barrington, "Understanding Citizenship Policy in the Baltic States," in From MIGRANTS to CITIZENS: Membership in a Changing World, edited by Douglas B. Klusmeyer and Thomas Alexander Aleinikoff (Washington, D.C.: Carnegie Endowment for International Peace, 2000), 253-58.

${ }^{41}$ Kristine Kruma, "Checks and Balances in Latvian Nationality Policies: National Agendas and International Frameworks," in Citizenship Policies in the New Europe, edited by Rainer Bauböck, Bernhard Perchinig and Wiebke Sievers (Amsterdam: Amsterdam University Press, 2009), 69.

${ }^{42}$ Anon, "Regular Report from The Commission on Latvia's Progress towards Accession."

${ }^{43}$ Ibid.

${ }^{44}$ Roger Dale Petersen, Understanding Ethnic Violence: Fear, Hatred, and Resentment in Twentieth-Century Eastern Europe (Cambridge: Cambridge University Press, 2002), 149.

${ }^{45}$ Helen M. Morris, "President, Party and Nationality Policy in Latvia, 1991-1999," Europe-Asia Studies 56, no. 4 (2004): 543-69. 
${ }^{46}$ Ibid.

${ }^{47}$ Zepa, "Citizenship, Official Language, Bilingual Education in Latvia: Public Policy in the Last 10 Years."

${ }^{48}$ Inese Sūpule, "The Construction of National and Ethnic Identity in Online Discussions on Referenda Initiatives in Latvia," Baltic Journal of European Studies 2, no. 1 (2012): 119-37.

${ }^{49}$ Iveta Jurkane, "Referendum Whether to Make Russian Latvia's Second Official Language or Not," Balti Worlds, March 2012.

${ }^{50}$ Aleks Tapinsh, "Russian Language Vote Shows Ethnic Split in Latvia,” 2012.

${ }^{51}$ Gederts Gelzis, "Latvia's Language Referendum Raises Question of National Identity,” Deutsche Welle 2012, available at https://www.dw.com/en/latvias-language-referendum-raises-question-of-national-identity/a15699273 , last accessed 22 March $2018 .$.

${ }^{52}$ Vladimir Socor, "Latvian Language Wins Referendum While Russian Party Shows Nuisance Potential," Eurasia Daily Monitor 9, no. 36 (2012).

${ }^{53}$ Šupule, "The Construction of National and Ethnic Identity in Online Discussions on Referenda Initiatives in Latvia."

${ }^{54}$ Ibid.

${ }^{55}$ Anon, "Latvians Reject Russian as Official Language," The Guardian 2012.

${ }^{56}$ Jurkane, "Referendum Whether to Make Russian Latvia's Second Official Language or Not."

${ }^{57}$ Vladimir Socor, "Latvia's Russian Party Triggers Constitutional Referendum on State Language (Part Two)," Eurasia Daily Monitor 9, no. 34 (2012).

${ }^{58}$ Ibid.

${ }^{59}$ Ibid.

${ }^{60}$ David M Herszenhorn, "Latvians Reject Russian as Second Language,” RFE / RL2012.

${ }^{61}$ Šupule, "The Construction of National and Ethnic Identity in Online Discussions on Referenda Initiatives in Latvia."

${ }^{62}$ Maria M. Kovacs and Judit Toth, "Kin-State Responsibility and Ethnic Citizenship: The Hungarian Case," in Citizenship Policies in the New Europe, edited by Rainer Bauböck, Bernhard Perchinig and Wiebke Sievers (Amsterdam: Amsterdam University Press, 2009), 159.

${ }^{63}$ Kovacs and Toth, "Kin-State Responsibility and Ethnic Citizenship: The Hungarian Case."

${ }^{64}$ Ibid.; Weinstein, "Hungary's Referendum on Dual Citizenship."

${ }^{65}$ Mária M. Kovács, "The Politics of Non-Resident Dual Citizenship in Hungary," Minority, Ethnicity and Society Review 8, no. 1 (2005): 53.

${ }^{66}$ Anon, "Hungary to Hold Controversial Referendum on Citizenship and Health Privatisation."

${ }^{67}$ Tünde Puskás,'We Belong to Them": Narratives of Belonging, Homeland and Nationhood in Territorial and Non-Territorial Minority Settings (Brussels: P.I.E. Peter Lang, 2009), 87-88.

${ }^{68}$ Kovacs and Toth, "Kin-State Responsibility and Ethnic Citizenship: The Hungarian Case"; Stephen M. Saideman and R. William Ayres, For Kin or Country: Xenophobia, Nationalism, and War (New York: Columbia University Press, 2008).

${ }^{69}$ Kovacs and Toth, "Kin-State Responsibility and Ethnic Citizenship: The Hungarian Case."

${ }^{70}$ Weinstein, "Hungary's Referendum on Dual Citizenship."

${ }^{71}$ Ibid.

${ }^{72}$ Kovacs and Toth, "Kin-State Responsibility and Ethnic Citizenship: The Hungarian Case."

${ }^{73}$ Ibid.

${ }^{74}$ Igor Štiks, "Nationality and Citizenship in the Former Yugoslavia: From Disintegration to European Integration," Southeast European and Black Sea Studies 6, no. 4 (2006): 490.

${ }^{75}$ Felicita Medved, "From Civic to Ethnic Community? The Evolution of Slovenian Citizenship," in Citizenship Policies in the New Europe, edited by Rainer Bauböck, Bernhard Perchinig and Wiebke Sievers (Amsterdam: Amsterdam University Press, 2009), 308.

${ }^{76}$ Štiks, "Nationality and Citizenship in the Former Yugoslavia: From Disintegration to European Integration."

77 "Slovenia | Freedom House," 2006. 
${ }^{78}$ Alenka Krašovec and Simona Kustec-Lipicer, "Election Briefing No 18 Europe And the Parliamentary Elections in Slovenia, October 2004," European Parties Elections and Referendums Network, 2004, 3-4.

${ }^{79}$ Medved, "From Civic to Ethnic Community? The Evolution of Slovenian Citizenship."

${ }^{80}$ Brad K. Blitz, "Statelessness and the Social (De)Construction of Citizenship: Political Restructuring and

Ethnic Discrimination in Slovenia," Journal of Human Rights 5, no. 4 (2006): 465.

${ }^{81}$ The Constitution of the Republic of Slovenia, 2004, available at

www.wipo.int/wipolex/en/text.jsp?file_id=180804 (accessed 11 June 2018).

${ }^{82}$ Blitz, "Statelessness and the Social (De)Construction of Citizenship: Political Restructuring and Ethnic Discrimination in Slovenia."

${ }^{83}$ Jelka Zorn, "Slovenia: Ethnic Exclusion in a Model Accession State," in Minority Rights in Central and Eastern Europe, edited by Bernd Rechel (Abingdon: Routledge, 2009), 220.

${ }^{84}$ Anon, "Slovenes Vote against Restoring Minority Rights," Euractiv 2010.

${ }^{85}$ Zorn, "Slovenia: Ethnic Exclusion in a Model Accession State."

${ }^{86}$ Medved, "From Civic to Ethnic Community? The Evolution of Slovenian Citizenship."

${ }^{87}$ Herszenhorn, "Latvians Reject Russian as Second Language."

${ }^{88}$ Anon, "Latvians Reject Russian as Official Language."

${ }^{89}$ Šupule, "The Construction of National and Ethnic Identity in Online Discussions on Referenda Initiatives in Latvia."

${ }^{90}$ Jurkane, "Referendum Whether to Make Russian Latvia's Second Official Language or Not."

${ }^{91}$ Kevin O’Connor, The History of the Baltic States (Westport: Greenwood Press, 2003), 176.

Sergiu Gherghina is a Lecturer in Comparative Politics at the Department of Politics, University of Glasgow. His research interests lie in party politics, legislative and voting behavior, democratization, and the use of direct democracy.

Nanuli Silagadze is a PhD candidate at the Department of Political Science, Åbo Akademi University. Her research interests lie in the fields of direct democracy, public opinion and voting behavior.

Figure 1: A Typology to Analyze Interethnic Referendums

\begin{tabular}{l|l|l|}
\multicolumn{1}{c}{} & \multicolumn{1}{c}{ Maintain status-quo } & \multicolumn{1}{c|}{ Change status-quo } \\
\cline { 2 - 3 } $\begin{array}{l}\text { Agenda-setting } \\
\text { Policy legitimation }\end{array}$ & & \\
\cline { 2 - 3 } & &
\end{tabular}

Figure 2: The Drivers of Interethnic Referendums in Central and Eastern Europe

\begin{tabular}{|c|c|c|}
\hline & Maintain status-quo & Change status-quo \\
\hline Agenda-setting & & $\begin{array}{c}\text { Hungary } 2004 \\
\text { Latvia } 2012\end{array}$ \\
\hline Policy legitimation & $\begin{array}{l}\text { Latvia } 1998 \\
\text { Slovenia } 2004\end{array}$ & Estonia 1992 \\
\hline
\end{tabular}

